\title{
INCORPORATING SUSTAINABILITY PRINCIPLES INTO ARCHITECTURAL DESIGN EDUCATION: RESULTS OF AN EXPERIMENTAL DESIGN STUDIO
}

\author{
Kamal Eldin Mohamed ${ }^{1}$ and Soofia Tahira Elias-Ozkan²
}

\begin{abstract}
Design is a structured process or a tactical guideline to accomplish a unique expectation of a product, while a design studio is the environment where students are taught the skills to design the product, which may be a building. Hence, the design studio course is the most important component of the architectural education curriculum; it is where the students get an opportunity to apply the theoretical knowledge gained through lecture-based courses. Yet most theory is not put into practice; consequently, the principles of sustainable design solutions are developed. There is an urgent need to teach future architects how to integrate sustainable design principles into their projects in order to prevent or mitigate environmental degradation due to the negative impacts of building projects. This experimental study initiated a new design studio pedagogy and a novel teaching structure for integrating sustainability principles into the architectural design projects of 3 rd year students. It also evolved a testing method to assess the success of the new pedagogy and the students' final design projects. This paper presents the results of the experimental design studio and delivers recommendations for subsequent sustainable design studio courses.
\end{abstract}

\section{KEYWORDS}

architectural education, design studio pedagogy, sustainability.

\section{INTRODUCTION}

Architectural education prepares students for their professional lives by teaching them design skills and theoretical and technical knowledge. The architecture profession is an interdisciplinary field that involves engineering, arts, environmental science, computer science, sociology, geography, culture, information technology, political science, and legal disciplines (Yu 2014). For this reason, the curriculum for Architectural education has a unique set up, which is distinct from curricula for other disciplines. It has special core subject, which is design.

Architectural education defines architecture as a conceptual problem-solving discipline; its goal is to produce conceptual thinkers who are well versed in the skills, science, theory, and history of their field. The success of the education program depends on the quality of the faculty members and students connected with their commitment and passion (Cornell

1. Department of Architecture, Izmir Institute of Technology

2. Department of Architecture, Middle East Technical University 
University 2015). Design is the product of a strategic approach or a roadmap of someone trying to accomplish a unique expectation (Bakarman 2003). The design studio is a special and major element in the architectural education, not only as course materials, but also as a place where the students practice design. Successful architecture studio courses are those that integrate the practice of design activity with all other coursework and educational experiences (Kurt 2012). A design jury is the assessment tool used to evaluate the product of the design studio work. The jury system embraces the strengthening of the learning process in addition to measuring the acquisition and application of knowledge (Anthony 1991).

Sustainability has been defined as fulfilling the demands of the present without jeopardizing the ability of future generations to fulfill their own demands. Sustainability education is an imperative that requires a paradigm shift in academic and professional training platforms (United-Nations 1987) (Altomonte et al. 2014).

The complex body of knowledge related to sustainable buildings has been included in the architectural education curriculum in many architectural schools in order to prepare their students to practice sustainable design. However, there is no clear consensus regarding pertinent teaching methods or curriculum design (Dib and Adamo-Villani 2014).

Over the last two decades, the integration of sustainability principles into architectural education has been actively debated. All parties agree that architectural education must be reformed to address sustainability and that every architectural program should make a relevant contribution in achieving this goal. The adaptation of content and ideas of sustainability will vary between architectural schools due to differences in pedagogical approaches, diversification of philosophy, and the flexibility and ability of adapting innovation into the curriculum (Ibrahim 2008).

It is essential to consider major restructuring of both the traditional design studio course and the modules for integrating sustainability principles. To this end, both teachers and students need to make a commitment to adapting a new studio pedagogy and make it their priority. Existing teaching methods, approaches, and techniques, which focus on lectures and assignments to equip students primarily with theoretical knowledge are not applicable for integrating sustainability issues in the design studio (Nikolic et al. 2010, Sarhan and Rutherford 2014).

\section{PROBLEMS AND OBJECTIVES}

Sustainable-design education requires a paradigm shift in academic and professional training. A thorough literature review has helped identify certain issues that hinder this essential paradigmatic shift; these issues are:

- Outdated pedagogy that focuses mainly on the form and aesthetics (Lofthouse 2013).

- Architecture students are not trained to work with other related disciplines (Yu 2014).

- Knowledge concerning environment, technology, and materials is lacking (Taleghani, Ansari, and Jennings 2011).

- Design courses focus on creating an individual character not on the collaborator individual (Buchanan 2012b).

- Most schools use digital technology as a computer aided drafting (CAD) tool, while digital technology should be fully integrated into the whole design process (Yu 2014).

Despite these obstacles and drawbacks, it was considered imperative to devise a method for achieving a paradigm shift, and a "sustainable design studio" was initiated as an experiment with 
a different pedagogical approach. This experiment was conducted with the belief that integrating sustainability principles in the design studio would help students produce sustainable design solutions for their architectural projects. The aim was to integrate sustainability principles into the design studio project as the basic concern of the whole design concept. While the objective of the proposed design studio pedagogy was to:

- Develop a method of integration.

- Test the integration method.

- Test the method's impact on students' learning abilities and the level of integration in the designed projects.

\section{METHODOLOGY}

The proposed sustainable architecture design studio (SADS) course focused on practicing rather than just acquiring theoretical knowledge, which would help in integrating sustainability in the design project.

The experimental design studio teaching methodology encompassed the following concepts from other schools of thought:

- The three principles of the Ecole des Beaux-Art: freedom, competition, and variety (Carlhian 1979).

- The Bauhaus prime education objectives that depend on integrating theory and application (Whitford 1992).

- Constructivist design studio concepts (Kurt 2012).

- Integrated public interest design studio concept (Anderson 2012).

- Charrette design studio technique (Pernice 2013).

- Embracing deep learning approach for principles and practices of sustainability (Sarhan and Rutherford 2014).

- Learning pyramid principles that support deep leaning not service learning. Therefore, the approach was to explain, compare, and construct, not describe (Wood 2004).

The fourteen weeks of the semester were divided into a modules system that allowed students to focus on the design process and not only on the final design/product. The design process was divided into four periods--four weeks for developing the conceptual idea, four weeks for project development, four weeks for material selection and testing their impacts, and two weeks for finishing and presentation of the design project. Each period ended with an open jury that evaluated the students' progress and performance.

\section{MATERIALS AND METHOD EXECUTION}

The experimental studio was executed in the Architecture Department at the Izmir Institute of Technology (IYTE), Turkey. The research was conducted in the third year architectural design studio course, "AR 302 Architectural Design IV," with 22 students (13 female and 9 male), during the spring term of 2015. Two instructors conducted the design studio as a team, supervising the work of all students with the help of one teaching assistant. The studio class consisted of twelve working hours per week. The design studio pedagogy was based on 8 teaching/learning techniques that are presented in Table 1 . These are as follows: Learning by doing; Learning by 
teaching others; Learning by demonstration; Learning through audio-visuals/ lectures; Deep learning; Practice by doing; Group discussions; and Integrating public interest

\section{Studio model}

The Design studio syllabus, studio calendar, project program, grading system, and jury's evaluations incorporated all research teaching methods; however, the environmental aspect of the sustainability principles was the only concern for the initial experimental design studio. The other two, i.e. social and economic aspects of sustainability were not considered. The entire evaluation of the students' work was divided into two parts. The first part was the design process evaluation, embracing the integration of sustainability (35\% of total grade). The second was the finished project evaluation (65\% of total grade); of which is $60 \%$ was dedicated purely to the design aspect and $40 \%$ to the degree of integration of the sustainability principles in the project (Table 2).

\section{Studio outcome}

Three student projects are presented in this section. The first one is an example of one of the best projects that had achieved a level of integration of sustainability principles and thus achieved a high reduction in energy consumption (56\%). The second project is an example of an average student project that had achieved some reduction (27\%) through sustainable measures. While the third project was one of the unsuccessful ones because of lack of integration and absence of building performance simulations to test the design.

Figures 1 and 2 illustrate two student projects that demonstrated successful integration of sustainability principles into their design, which started from the project concept to the finished design, as well as the energy performance simulations showing the savings in energy consumption and reduction in $\mathrm{CO}_{2}$ emissions.

Figure 3 illustrates an unsuccessful student project that neglected to include the major elements of sustainability principles such as natural light, natural ventilation, mass orientation, the

TABLE 1. The teaching elements and techniques of SADS.

\begin{tabular}{|l|l|l|}
\hline No. & Learning Technique & Teaching Elements of SADS Spring 2015 \\
\hline $\mathbf{1}$ & learning by teaching others & One case study was presented by each student (22 case studies) \\
\hline $\mathbf{2}$ & $\begin{array}{l}\text { practice by doing and group } \\
\text { discussion }\end{array}$ & $\begin{array}{l}\text { Students were required to write the project program } \\
\text { individually, then in a small group of three, then in a group of } \\
\text { eight }\end{array}$ \\
\hline $\mathbf{3}$ & practice by doing & $\begin{array}{l}\text { Students were required to construct study models during the } \\
\text { project design development process (4 models) }\end{array}$ \\
\hline \multirow{2}{*}{ deep learning } & $\begin{array}{l}\text { Biweekly panel reviews were conducted (6 panel reviews) in } \\
\text { two formats: }\end{array}$ \\
\cline { 2 - 3 } & group discussion & $\begin{array}{l}\text { A) Group discussion of the design process and project } \\
\text { development were conducted }\end{array}$ \\
\cline { 2 - 3 } & learning by demonstration & $\begin{array}{l}\text { B) Students criticized each others' projects by asking each } \\
\text { student to present his/her project to the group }\end{array}$ \\
\hline
\end{tabular}


TABLE 1. (Continued)

\begin{tabular}{|c|c|c|}
\hline No. & Learning Technique & Teaching Elements of SADS Spring 2015 \\
\hline \multirow[t]{3}{*}{5} & & Technical trips to \\
\hline & practice by doing & A) The project site and surrounding area \\
\hline & learning by demonstration & B) Existing exemplary projects \\
\hline 6 & practice by doing & $\begin{array}{l}\text { Instructors conducted biweekly charrette design assignments } \\
\text { during the design process ( } 4 \text { assignments) }\end{array}$ \\
\hline \multirow[t]{5}{*}{7} & practice by doing & $\begin{array}{l}\text { Various digital technologies were used throughout the design } \\
\text { process }\end{array}$ \\
\hline & & A) Conceptual design period; climate consultant and Sketchup \\
\hline & & $\begin{array}{l}\text { B) Design development period; Rivit, Auto CAD, and } \\
\text { Sketchup }\end{array}$ \\
\hline & & $\begin{array}{l}\text { C) Design evaluation period; Rivit, DesignBuilder, and } \\
\text { Sketchup }\end{array}$ \\
\hline & & $\begin{array}{l}\text { D) Final drawing and presentation; Rivet, Auto CAD, 3D } \\
\text { Max, DesignBuilder, and Sketchup }\end{array}$ \\
\hline 8 & $\begin{array}{l}\text { public interest/immediate use } \\
\text { practice }\end{array}$ & $\begin{array}{l}\text { Project owner(s)/user(s) were invited to discuss the project ( } 2 \\
\text { visits) }\end{array}$ \\
\hline \multirow[t]{2}{*}{9} & learning by demonstration & $\begin{array}{l}\text { Monthly Outside expert(s) were invited for workshop (3 } \\
\text { workshops) }\end{array}$ \\
\hline & practice by doing & $\begin{array}{l}\text { A) Instructors assigned homework related assignments ahead of } \\
\text { each workshop studie }\end{array}$ \\
\hline 10 & learning by demonstration & $\begin{array}{l}\text { Instructors conducted individual desk critiques (10 desk } \\
\text { critiques) }\end{array}$ \\
\hline 11 & $\begin{array}{l}\text { learning by visual, audio, and } \\
\text { lecture }\end{array}$ & $\begin{array}{l}\text { Class instructors offered lectures about the project topics that } \\
\text { included visual and audio materials (6 Lectures) }\end{array}$ \\
\hline \multirow[t]{3}{*}{12} & & Juries \\
\hline & learning by demonstration & A) Instructors conducted midterm juries ( 3 midterm juries) \\
\hline & learning by teaching others & $\begin{array}{l}\text { B) Instructors hosted a final jury that included the University } \\
\text { Rector (project owner), academic members }\end{array}$ \\
\hline
\end{tabular}

TABLE 2. SADS's grading system to evaluate of student's performance and their design projects.

\begin{tabular}{|c|c|c|c|c|c|c|c|c|}
\hline \multicolumn{9}{|c|}{ SADS Grade Distribution (100 points) } \\
\hline \multicolumn{7}{|c|}{ Design Process 35 Points } & \multicolumn{2}{|c|}{ Final Jury 65 Points } \\
\hline $\begin{array}{l}\text { Site } \\
\text { analysis } \\
\& \text { group } \\
\text { model } \\
\text { \& case } \\
\text { studies }\end{array}$ & $\begin{array}{l}\text { Assignments } \\
\& \text { charrette } \\
\text { work }\end{array}$ & $\begin{array}{l}\text { Attendance } \\
\& \text { class } \\
\text { performance }\end{array}$ & $\begin{array}{l}\text { First } \\
\text { midterm } \\
\text { Jury }\end{array}$ & $\begin{array}{l}\text { Second } \\
\text { midterm } \\
\text { Jury }\end{array}$ & $\begin{array}{l}\text { Third } \\
\text { midterm } \\
\text { Jury }\end{array}$ & Portfolio & $\begin{array}{l}\text { Sustainability } \\
\text { checklist } \\
\& \text { energy } \\
\text { simulation test } \\
40 \%\end{array}$ & $\begin{array}{l}\text { Design } \\
\text { evaluation } \\
60 \% \\
\end{array}$ \\
\hline (5 Points) & (5 Points) & (5 Points) & (5 Points) & (5 Points) & (5 Points) & (5 Points) & (26 Points) & (39 Points) \\
\hline
\end{tabular}


FIGURE 1. The successful student's project incorporated the use of natural light, natural ventilation, sustainable materials (totally constructed out of wood), double skin façade, shading elements, green elements, rain water collection, reuse of gray water, and solar panels. The proposed design had achieved a $56 \%$ reduction in annual energy consumption.

\section{Eray Mustafa Inanç}
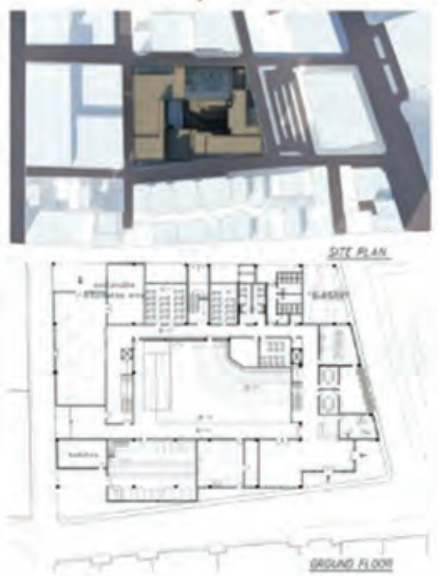

trous
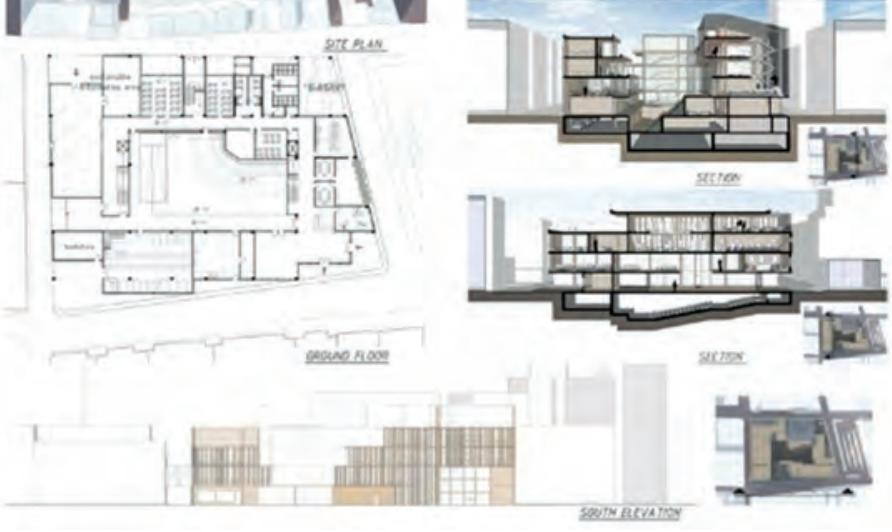
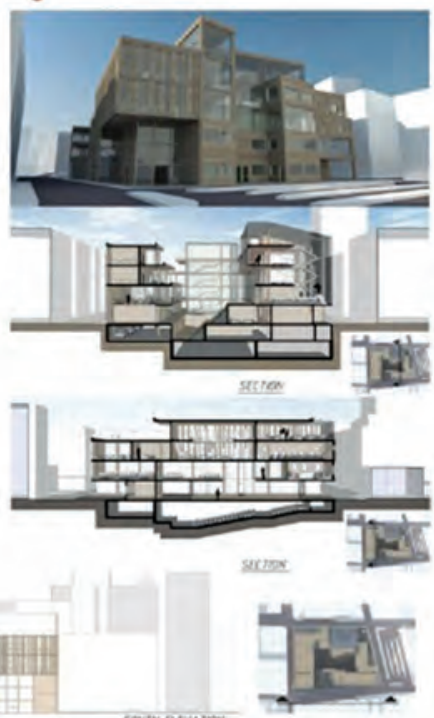
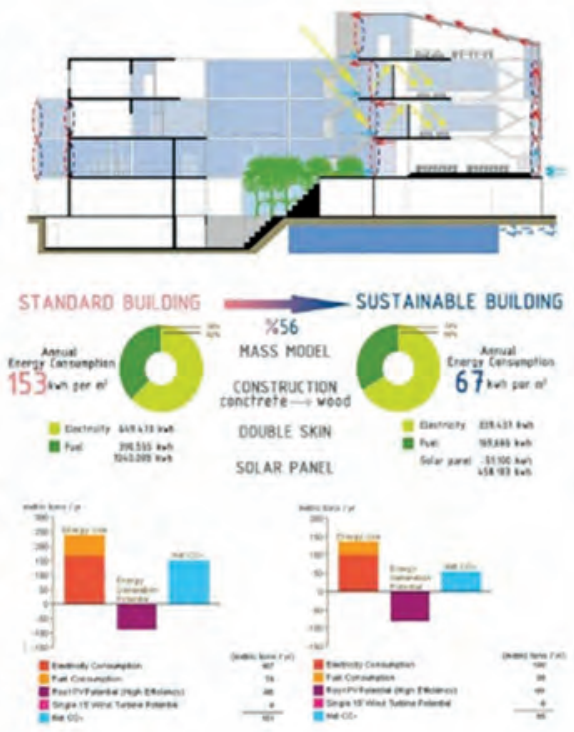

FIGURE 2. The average student's project incorporated the use of natural light, natural ventilation with central court and narrow floor plans, sustainable materials (constructed out of steel), double skin façade, shading elements, green roofs, rain water collection, reuse of gray water, and solar panels. The proposed design had $27 \%$ reduction in annual energy consumption and $30 \%$ in $\mathrm{CO}_{2}$ emission.
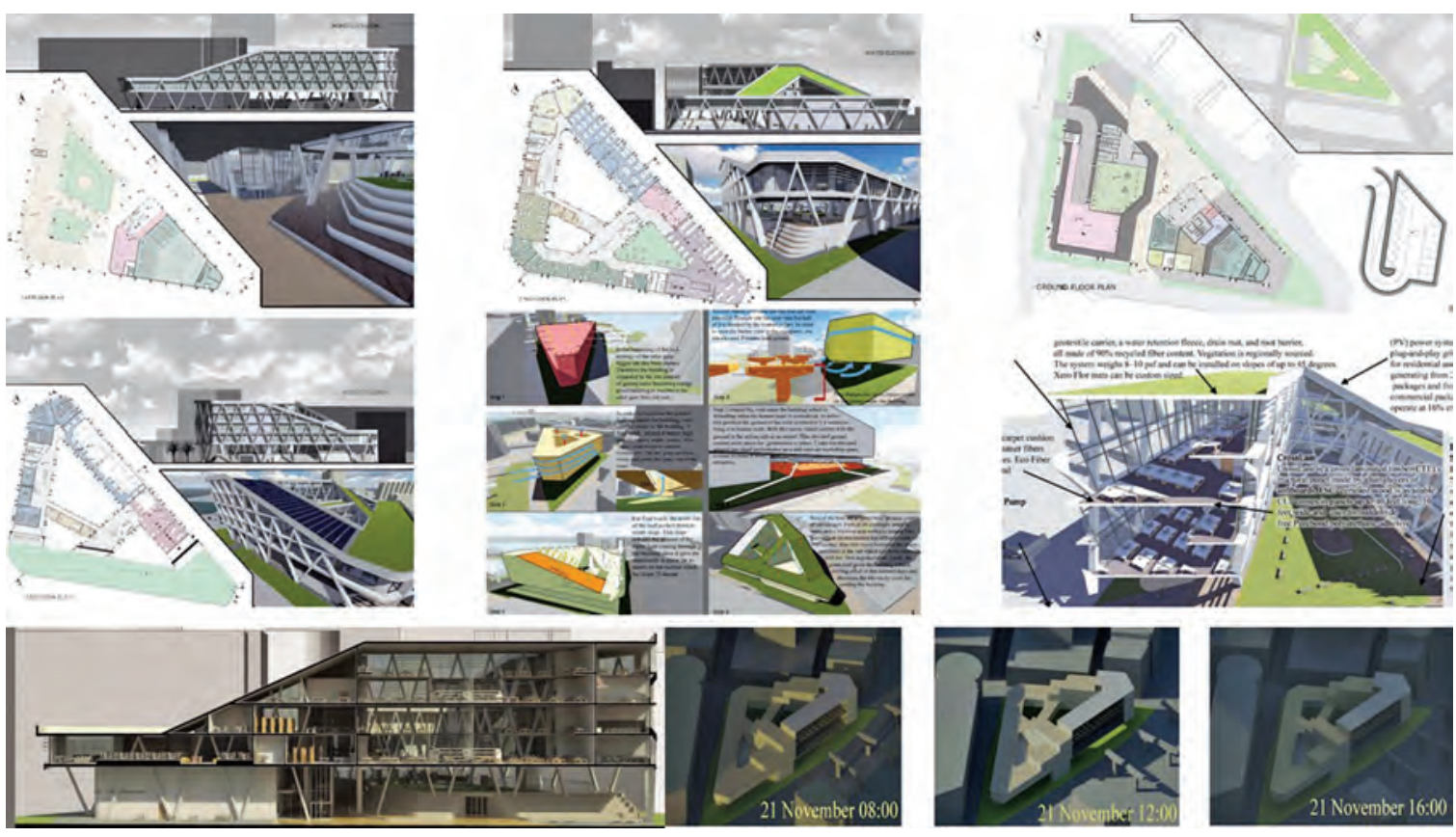
FIGURE 3. This student project neglected to provide enough natural light in most working spaces as well as natural ventilation Most of the sustainable design elements were not integrated in the design

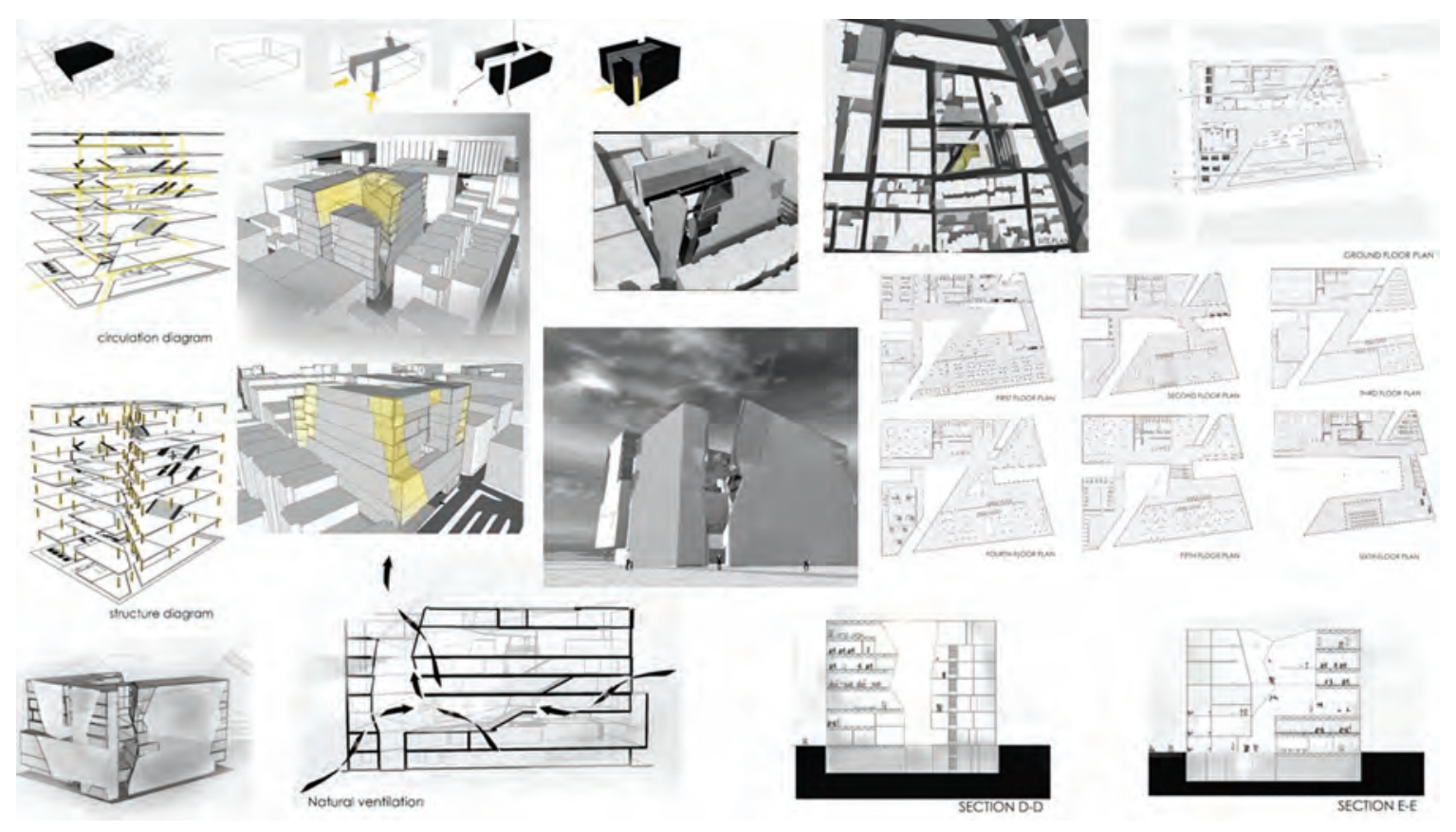

use of sustainable and natural materials etc. Furthermore, the student did not run the building performance simulations to test the energy consumption and $\mathrm{CO}_{2}$ emission value.

\section{EVALUATION AND ASSESSMENT}

The sustainable architectural design studio instructors carried out the evaluation of the students' work, which was based on the design process they had followed and their final product: their design project, as well as the degree to which the sustainability principles were integrated into their final designs. In addition, the students assessed the perceived value of the studio teaching methods and tools in achieving program goals.

\section{Instructors' Evaluation of the Students' Work}

The sustainability principles checklist, adapted from (Karslı 2013), was revised and expanded to be used in the architectural design studio, and then given to the students during the design process. The studio instructors explained all elements of the checklist to the students and showed them how to integrate each element in their design project, guiding them throughout the design process. At the end of the semester, each project was evaluated against the sustainability checklist, which was the yardstick to measure project success ( $40 \%$ of the final project evaluation grades). Table 3 presents the checklist elements, while Figure 4 illustrates the frequency of use of each sustainable design element in the 22 projects.

In order to understand the impact of the sustainability principles on the design process and the project grade, the relationships between these variables were determined. Figure 5 illustrates the positive correlation between the number of sustainable elements in each student's project 
TABLE 3. Sustainability checklist elements and grading system.

\begin{tabular}{|c|c|c|c|c|c|c|c|c|c|c|c|c|c|c|c|c|c|c|c|c|c|c|}
\hline & & & & & $\operatorname{ergy}($ & $15 \mathrm{Po}$ & ints & & & & & $\begin{array}{l}\text { ater } \\
\text { Poir }\end{array}$ & & & $\begin{array}{l}\text { Vater } \\
\text { Points }\end{array}$ & & & $\begin{array}{r}\text { Heal } \\
\text { Poi }\end{array}$ & & & & \\
\hline & & $\begin{array}{l}\text { Red } \\
\text { the } \\
\text { ene } \\
\text { use } \\
\text { ligh }\end{array}$ & $\begin{array}{l}\text { ucing } \\
\text { gy } \\
\text { for } \\
\text { ing }\end{array}$ & & $\begin{array}{l}\text { ucing } \\
\text { gy } \\
\text { for } \\
\text { ila- }\end{array}$ & & $\begin{array}{l}\text { duci } \\
\text { rgy } \\
\text { hea } \\
\text { d co }\end{array}$ & $\begin{array}{l}\text { used } \\
\text { ing } \\
\text { ling }\end{array}$ & & le & & & & & & & & & & & & \\
\hline 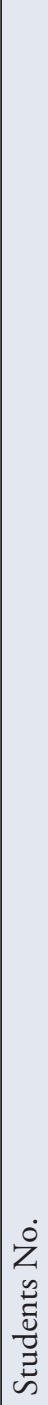 & 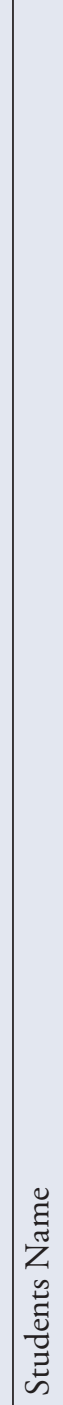 & 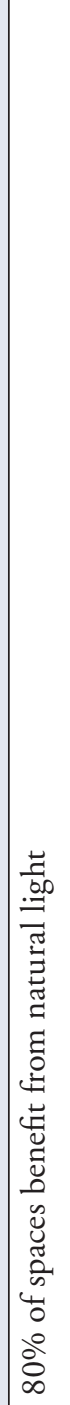 & 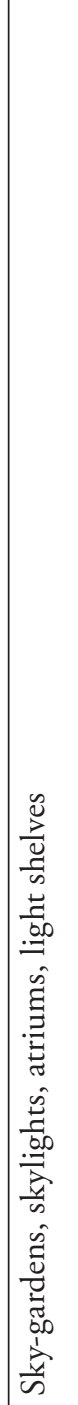 & 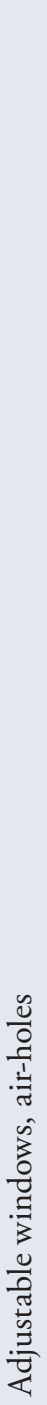 & 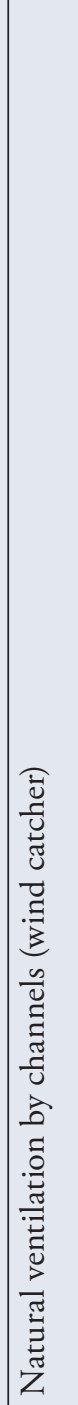 & 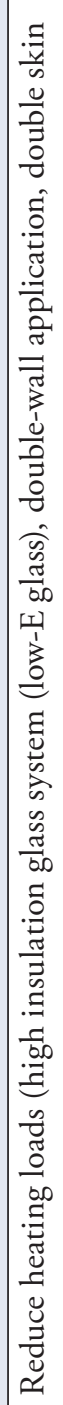 & 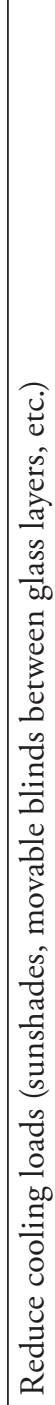 & 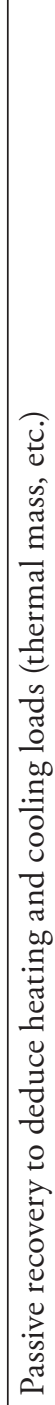 & 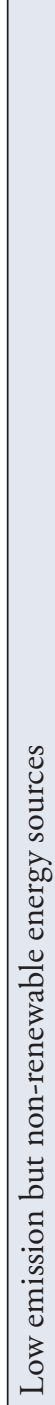 & 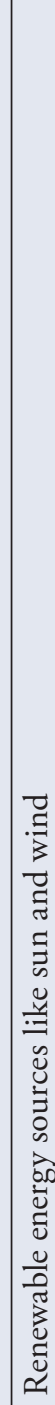 & 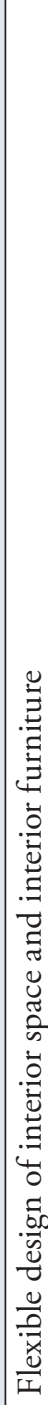 & 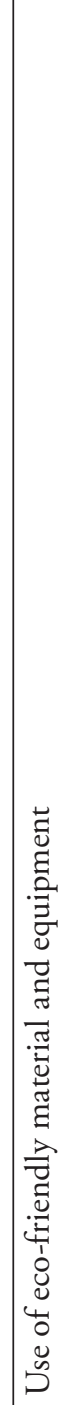 & 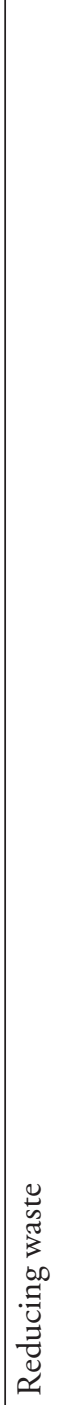 & 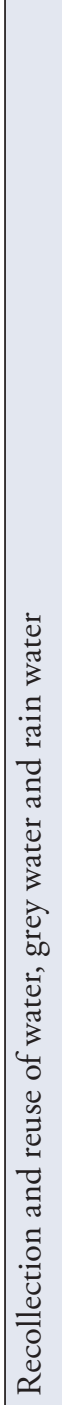 & 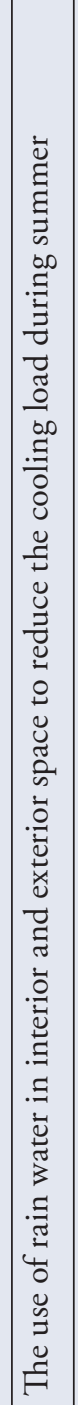 & 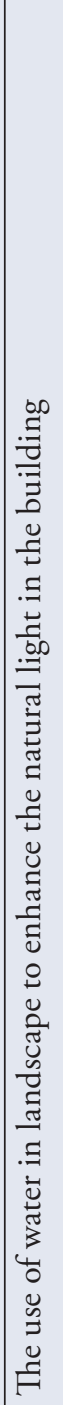 & 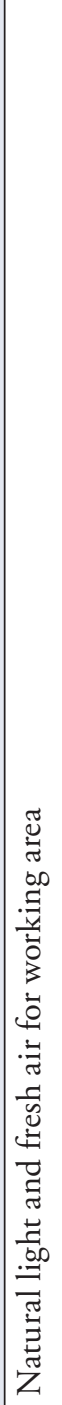 & 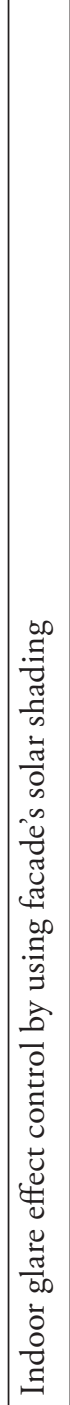 & 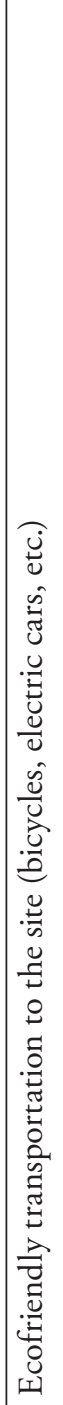 & 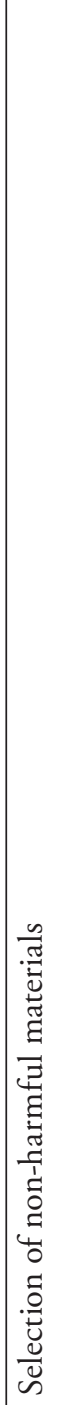 & 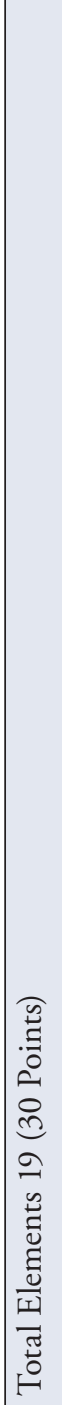 & 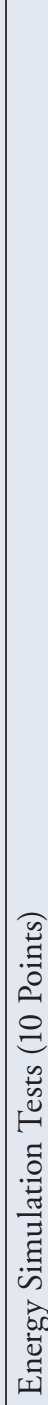 \\
\hline & & & & & & & & & & & & & & & & & & & & & & \\
\hline & & & & & & & & & & & & & & & & & & & & & & \\
\hline & & & & & & & & & & & & & & & & & & & & & & \\
\hline
\end{tabular}


FIGURE 4. The frequency of use of each sustainable design element in the 22 student projects.

The Frequency of Use of Each Element in 22 Projects

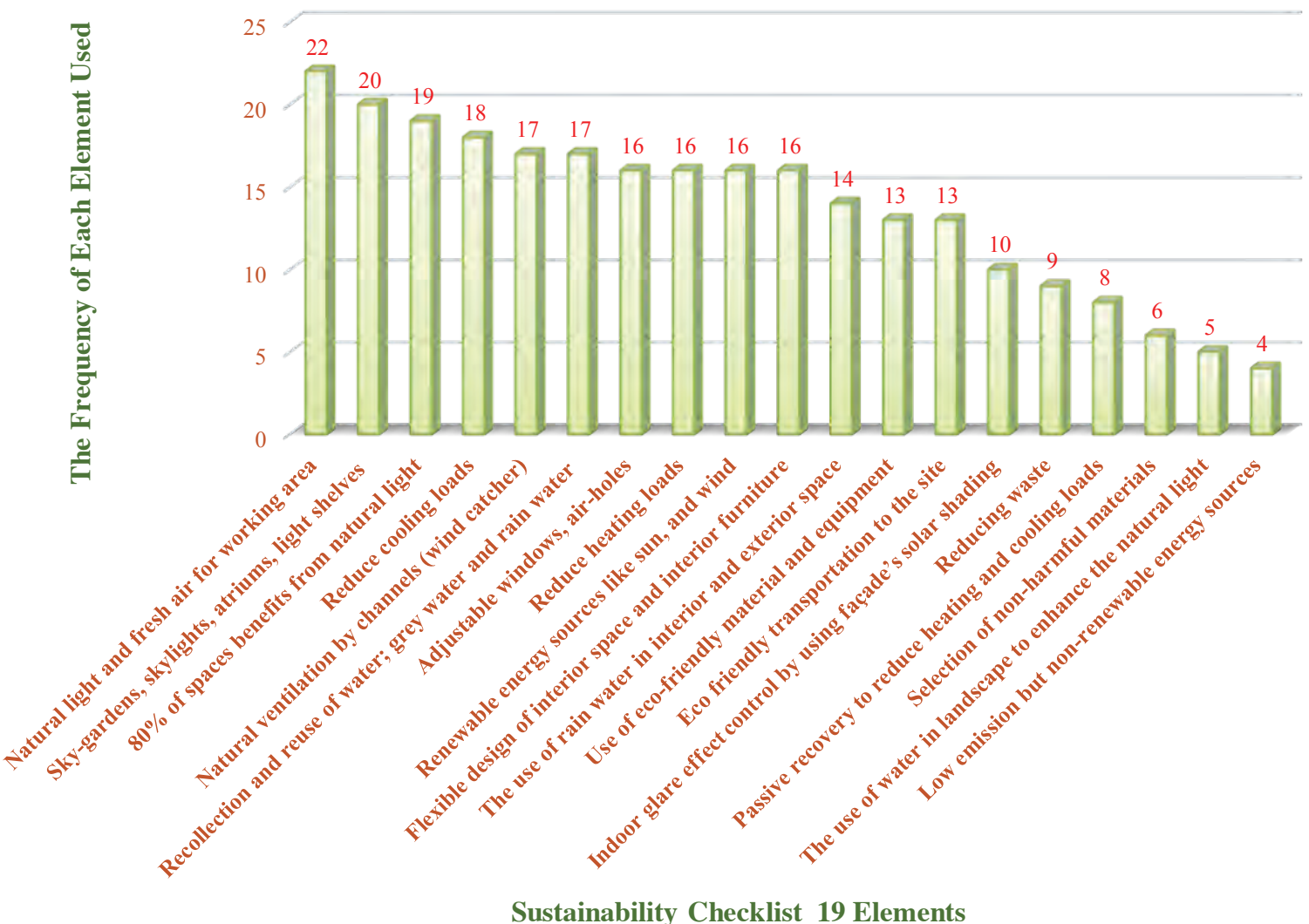

FIGURE 5. The correlation between the number of sustainable elements each student used in his/her project and the final grades.

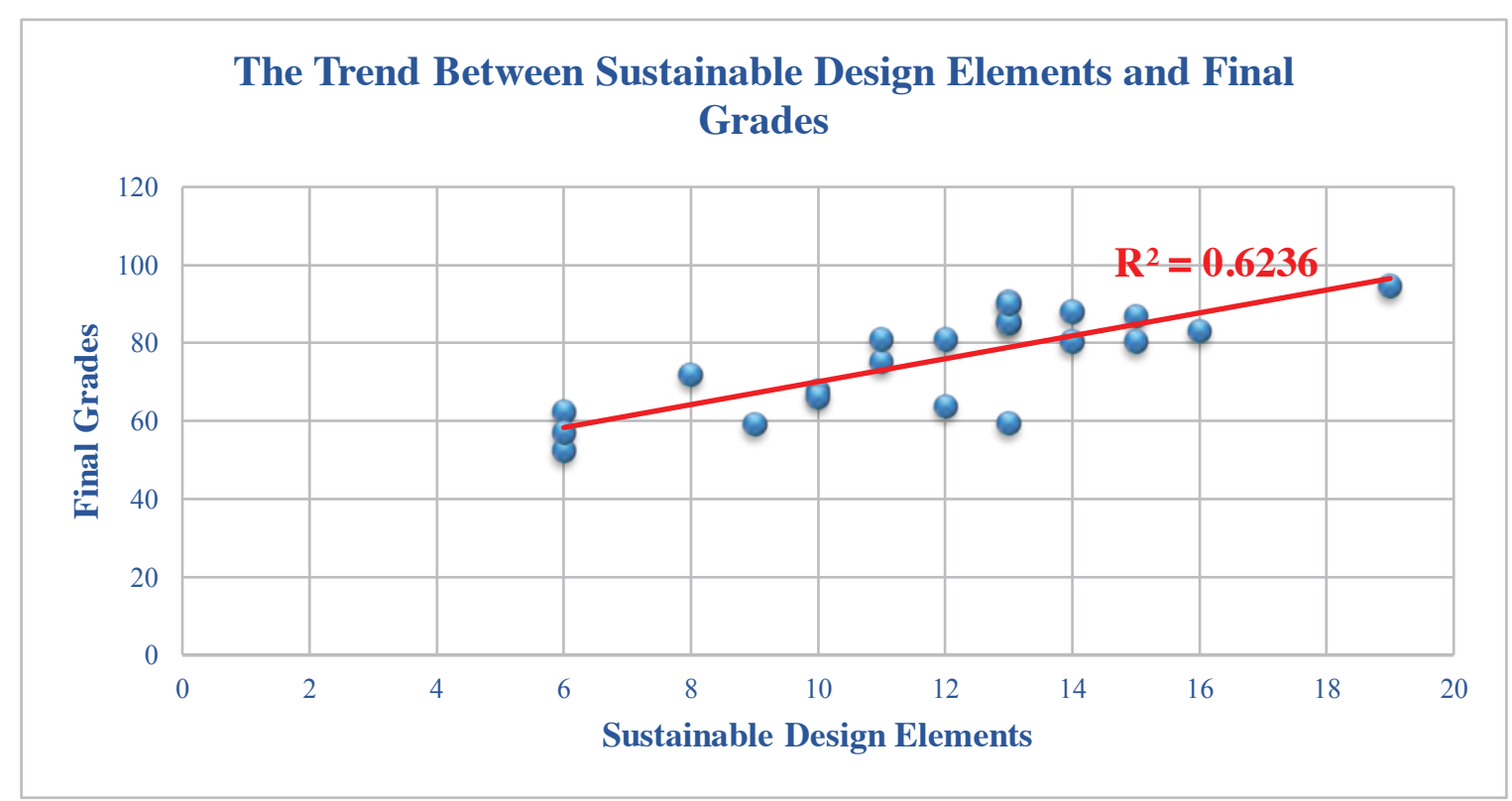


FIGURE 6. A positive correlation is seen between design process grades and final studio grades.

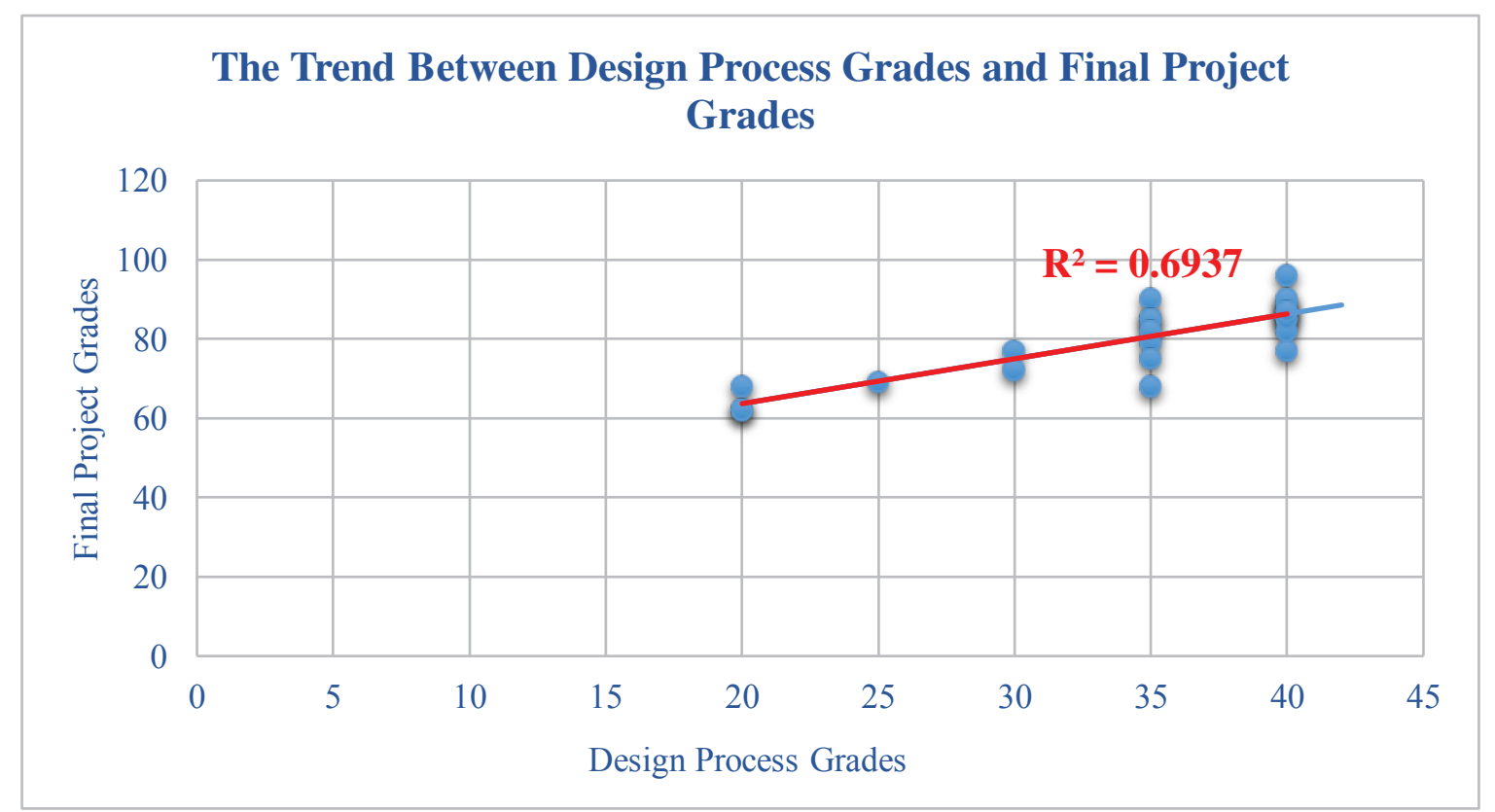

and their final studio grade. Additionally, the relationship between design process grades representing the new studio pedagogy structure and the grade for the final project of the students show a positive trend (Figure 6).

\section{Students' assessment of the SADS pedagogy}

One week after the final jury, when the grades had been announced, the instructors invited the students for an open colloquium regarding the experimental studio. The students were handed a survey form that had various questions regarding sustainability issues, studio structure and format, jury style and format, as well as their own comments about the course. One important outcome of this survey was that though $80 \%$ of the students had no knowledge of sustainable design principles before attending the studio, $95 \%$ of the students confirmed that they would like to practice sustainable design in their professional life. They also expressed their preference for furthering their knowledge on this subject during their graduate studies.

The students had been asked to rate the sustainable architectural design studio pedagogy by scoring the teaching and learning elements of the design course. The data collected from the survey is summarized in Figure 7 below, and it shows that the case studies and technical trips scored the highest points among the studio activities and the use of digital media to simulate building performance of the student's design scored the least points. This was probably because they were using the simulation programs for the first time and did not have enough time to fully familiarize themselves with the programs before the end of the term when their designs had matured.

The students were also asked to rate the sustainable design principles in order of preference to use in their projects; this data is summarized in Figure 8. It can be seen that natural light scored the highest points among the sustainable design elements and was followed closely by natural ventilation, while eco-transportation scored the least within the students' consideration. 
FIGURE 7. Pedagogy structure elements average scored points.

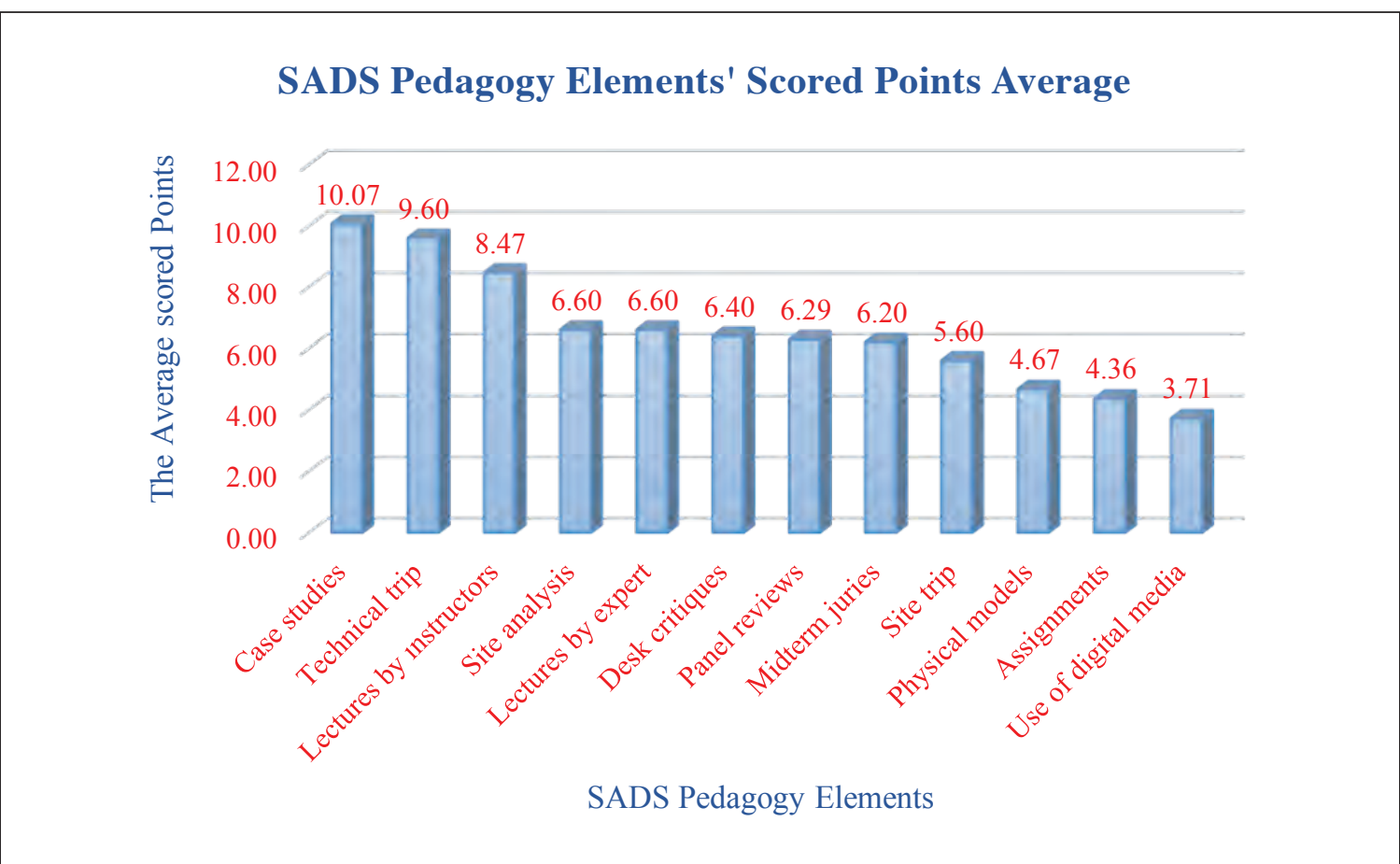

FIGURE 8. The average scored points of principles design elements of the initial experimental studio.

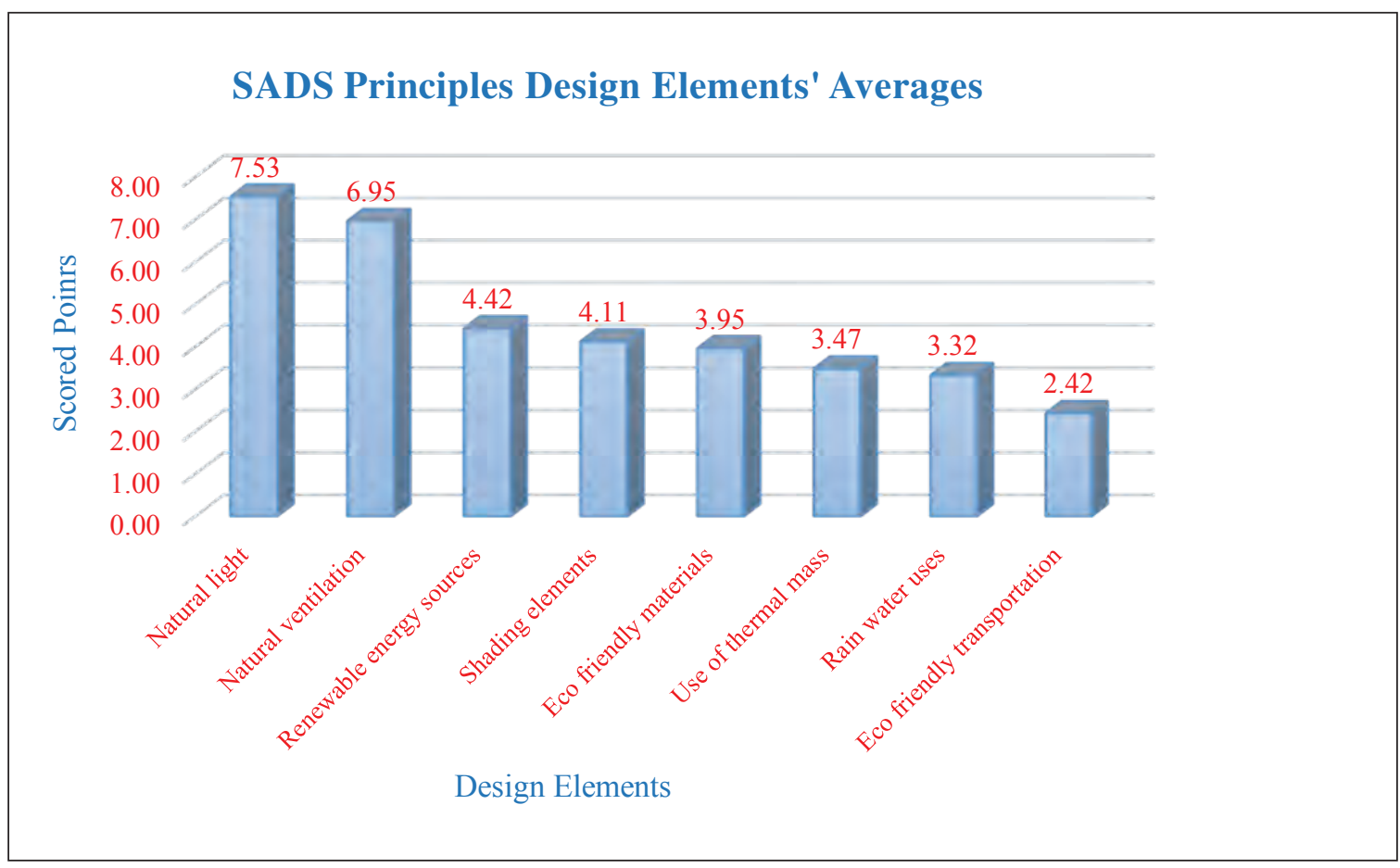


In general, students appreciated their time in the sustainable design studio and enjoyed learning the subject matter. A few students complained about the higher workload in the sustainable design studio in comparison to the conventional design studio section running parallel to the experimental one.

Most students commented on the difficulties they had faced in trying to learn many sustainability design principles before coming up with a creative sustainable design solution. However, as can be anticipated, students who had attended the sustainable design elective courses in the past faced fewer difficulties. In addition, students indicated that the building performance simulations took a lot of time to learn and apply, and so they were not as successful as they would have like to be in this exercise. The use of three different building performance simulation (BPS) programs: Sketchup, DesignBuilder, and Revit created confusion among the students. The conversion among the three programs was difficult and in some cases impossible. Some buildings' forms were difficult to draw in DesignBuilder software as they required a higher expertise level than the students possessed. Importing drawings from Sketchup to DesignBuilder in some cases were unsuccessful. Revit achieved the most successful energy simulation result given the learning time required, other various work achievements, and reasonable measured results.

\section{CONCLUSIONS AND RECOMMENDATIONS}

The architecture department at IYTE aims to produce architects competent in the design and execution of sustainable buildings by offering a variety of technical courses, but the current, conventional design studio pedagogy does not support this aim. Students do not learn to integrate knowledge regarding sustainable approaches gained in the technical courses into their design projects. The experimental studio was an attempt at integrating sustainability principles into the architecture design studio, which in turn required the creation of a new studio pedagogy followed by an innovative teaching method that was supported by a firm timetable of studio activities and tasks. Guidance was given to the students to integrate sustainable design principles into their term projects through lectures, desk and board critiques, and technical site visits. Throughout the design process, students were required to perform tasks such as site analysis, case studies, analysis of the buildings visited during technical trips, charrette studio assignments, energy and daylight simulation, study models, and construction details drawings and present their work in class. Each task reflected positively on the final product: the students' final design projects. The experimental SADS was successful in helping to integrate sustainable design elements in the students' projects, with the average number of sustainable elements integrated into students' projects being 12 out of a total of 19 elements in the checklist.

Selection of jury members was made according to their expertise in sustainable design issues, which helped the students achieve their studio tasks. The use of BPS software to test building energy consumption and $\mathrm{CO}_{2}$ emission was also very useful in improving the level of integration.

The following recommendations were made for conducting subsequent Sustainable Architectural Design Studios (SADS):

Some of the teaching elements should rescheduled during the design process to maximize their benefits; e.g., case study presentations should be finished within the first six weeks, technical trips should be arranged as early as possible, and more experts in the sustainable design field should be invited to the SADS juries. 
A single BPS software should be used to evaluate energy consumption and $\mathrm{CO}_{2}$ emissions in order to reduce the task duration and effort.

The grade of design process should increase as well as the grades distributed for sustainability integration level; additionally, more emphasis should be put on building performance simulations and the degree of success in reducing energy consumption and $\mathrm{CO}_{2}$ production.

\section{ACKNOWLEDGEMENTS}

The authors would like to thank Dr. Zeynep Durmuş Arsan, Instructor, and Mumine Gercek, Teaching Assistant, for their valuable contribution to the sustainable architecture design studio, AR302, as well as the students who participated in this course in Spring 2015 at the Izmir Institute of Technology.

The Students of SADS class of spring of 2015
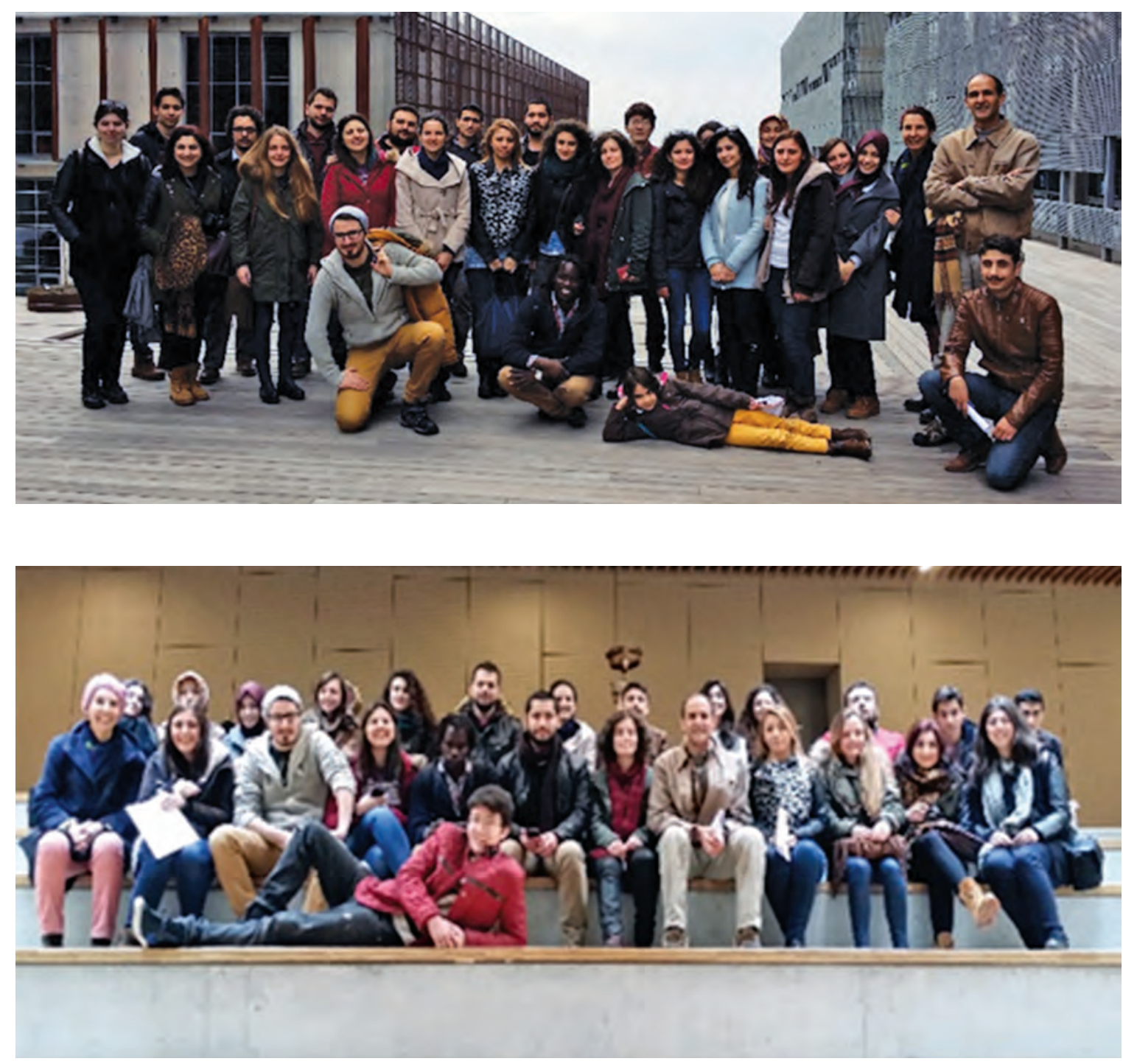


\section{REFERENCES}

Altomonte, Sergio, Hana Reimer, Peter Rutherford, and Robin Wilson. 2014. "Towards Education for Sustainability in University Curricula and in the Practice of Design'." Sustainable Architecture for a Renewable Future, Munich, Germany.

Anderson, Nadia M. 2012. "Public Interest Design: A Vehicle for Change in Architectural Education and Practice." 2012 ACSA International Conference, Barcelona, Spain.

Anthony, Kathryn H. 1991. "Design juries on trial: The renaissance of the design studio."

Bakarman, Ahmed Abdullah. 2003. "Quality evaluation tool for the design studio practice."

Buchanan, Peter. 2012b. "The Big Rethink: Rethinking Architectural Education.” V: Architectural Review 28.

Carlhian, Jean Paul. 1979. "The Ecole des Beaux-Arts: Modes and Manners." 7.

Cornell University. 2015. "Bachelor of Architecture (B.Arch.), Cornell University.” accessed 29.04. http://courses. cornell.edu/preview_program.php?catoid=22\&poid=10782\#barchcurriculumforstudentsmatriculatinginf all2014.

Dib, Hazar, and Nicoletta Adamo-Villani. 2014. "Serious sustainability challenge game to promote teaching and learning of building sustainability." Journal of Computing in Civil Engineering (5).

Ibrahim, Norhati. 2008. "Sustainability and the Architectural Education: Are we there yet." SENVAR+ ISESEE.

Karsl1, Umut Tuğlu. 2013. "Integrating Sustainability in Interior Design Studio.” Procedia—Social and Behavioral Sciences 106:1532-1539. doi: 10.1016/j.sbspro.2013.12.173.

Kurt, Sevinc. 2012. "Applying Constructivist Instruction Method to the Basic Design Course." International Journal of Arts and Sciences 05 (05):253-262.

Lofthouse, Natasha. 2013. “The Changing Nature of Architectural Education.” MA, Development and Emergency Practice, Oxford Brookes University.

Nikolic, Dragana, John I Messner, Sanghoon Lee, and Chimay Anumba. 2010. "The virtual construction simulator-development of an educational simulation game." Proceedings of the International Conference on Computing in Civil and Building Engineering.

Pernice, Kara. 2013. “Charrettes (Design Sketching): Half Inspiration, Half Buy-In.” Nielsen Norman Group, accessed 03.05. http://www.nngroup.com/articles/design-charrettes/.

Sarhan, Ahmed, and Peter Rutherford. 2014. "Integrating sustainability in the architectural design education process-taxonomy of challenges and guidelines." Fusion-Proceedings of the 32nd eCAADe Conference.

Taleghani, Mohammad, Hamid Reza Ansari, and Philip Jennings. 2011. "Sustainability in architectural education: A comparison of Iran and Australia.” Renewable Energy 36 (7):2021-2025. doi: http://dx.doi.org/10.1016/j. renene.2010.11.024.

United-Nations. 1987. "Report of the World Commission on Environment and Development: Our Common Future." Oxford: Oxford University Press.

Whitford, Frank. 1992. The Bauhaus: Masters \& Students by Themselves. London: Conran Octopus.

Wood, E. J. 2004. "Problem-Based Learning: Exploiting Knowledge of How People Learn to Promote Effective Learning." Bioscience Education e-Journal 3.

Yu, Fang Da. 2014. "Impact of digital technology on Architectural Design Teaching." Advanced Materials Research. 